\title{
Experimental Study on Strength Characteristics of Blended Geopolymer Mortar
}

\author{
Dia Eddin Nassani ${ }^{1 *}$ \\ ${ }^{1 *}$ Hasan Kalyoncu University, Faculty of Engineering, Departmant of Civil Engineering, Gaziantep, Turkey, (ORCID: 0000-0002-4196-8822), \\ diaeddin.nassani@hku.edu.tr
}

(First received 6 April 2021 and in final form 30 May 2021)

(DOI: 10.31590/ejosat.933751)

ATIF/REFERENCE: Nassani, D. E. (2021). Experimental Study on Strength Characteristics of Blended Geopolymer Mortar. European Journal of Science and Technology, (25), 70-74.

\begin{abstract}
This study investigates the effect of fly ash (FA) class F content and curing temperature on the compressive strength of Geopolymer Mortar (GPLM). GPLM is produced from FA mixed with the alkaline solution. The experimental test was performed on GPLM cubes with curing temperature of 70,90 and $110^{\circ} \mathrm{C}$ with curing period of one day. The alkaline activator was a combination of $12 \mathrm{M} \mathrm{NaOH}$ solution with sodium silicate in the ratio of $1: 2.5$. The ratio of alkaline solution to binder equal to 0.50 . Test results indicate that the increment in the FA content increases the compressive strength of GPLM. The strength increases with the increase of curing temperature of GPLM. Moreover, blended GPLM with high percentage of fly ash has less sorptivity.
\end{abstract}

Keywords: Curing, GPLM, Fly ash, Mortar, Compressive strength

\section{Jeopolimer Harcın Mukavemet Özellikleri Üzerine Deneysel Çalışma}

\section{Özet}

$\mathrm{Bu}$ çalışma, uçucu kül (FA) içeriğinin ve kür sıcaklığının Jeopolimer Harcın (GPLM) basınç dayanımı üzerindeki etkisini araştırmaktadır. GPLM, alkali çözelti ile karıştırılmış FA'dan üretilir. Deneysel test, bir günlük kürlenme süresi ile 70,90 ve $110^{\circ} \mathrm{C}$ kürleme sıcaklığı ile GPLM küpleri üzerinde gerçekleştirilmiştir. Alkalin aktivatör, 12M NaOH çözeltisinin 1: 2.5 oranında sodyum silikat ile bir kombinasyonuydu. Alkali çözeltinin bağlayıcıya oranı 0,50'ye eşittir. Test sonuçları, FA içeriğindeki artışın GPLM'nin basınç dayanımını artırdığını göstermektedir. GPLM'nin kürleme sıcaklığının artmasıyla mukavemet artar. Ayrıca, yüksek oranda uçucu kül içeren harmanlanmış GPLM daha az sorptiviteye sahiptir.

Anahtar Kelimeler: Kürleme, GPLM, Uçucu kül, Harç, Basınç dayanımı

\footnotetext{
${ }^{1}$ Corresponding Author: diaeddin.nassani@hku.edu.tr
} 


\section{Introduction}

It is widely known that the production of Portland cement consumes considerable energy and also contributes a large amount of $\mathrm{CO} 2$ to the atmosphere. However, Portland cement is still the main binder in concrete structure leading to the search for more environmentally friendly materials.

On the other hand, climate change due to global warming, one of the biggest environmental problems, has become a major concern in the last decade. Global warming is caused by the release of greenhouse gases such as $\mathrm{CO} 2$ into the atmosphere through human activities. Among the greenhouse gases, $\mathrm{CO} 2$ contributes about $65 \%$ of global warming [1]. The cement industry is responsible for about $6 \%$ of all $\mathrm{CO} 2$ emissions because one tonne of Portland cement production releases about one tonne of $\mathrm{CO} 2$ into the atmosphere $[1,2]$.

In this context, the GPLM technology proposed by Davidovits [3, 4] holds an important promise for application in the concrete industry as an alternative binder to Portland cement. In terms of reducing global warming, GPLM technology can reduce the $\mathrm{CO} 2$ emission caused by the cement industry to the atmosphere by about $80 \%$ [1].

A possible alternative is the use of an alkali activated binder using industrial byproducts containing silicate materials. The most common industrial by-products used as binder materials are fly ash (FA) and ground granulated blast furnace slag (GGBFS). While GGBFS is widely used as a cement replacement material due to its strength, fly ash has been used as a pozzolanic material to improve the physical, chemical and mechanical properties of concrete [5]. Fly ash is a coal combustion product that is composed of the particulates (fine particles of burned fuel) that are driven out of coal-fired boilers together with the flue gases.

The production material such as fly ash and slag within GPLM concrete also necessary to reduce approximately $5 \%$ of global Carbon dioxide emission instead of using OPC, industrial manufacture slag and fly ash increase up to $80 \%$ less greenhouse gas emissions. The opportunity of fly ash and Slag create a chance to use burning coal and iron, as a replacement for OPC. Portland cement replacing fly ash and slag as the binder increase the strength of GPLM concrete. The fly ashslag with presence of admixtures increases the high strength GPLM concrete.

Mechanical properties of GPLM are better than cement paste. Therefore, not only helps to generate less $\mathrm{CO} 2$ than OPC, but also one of the best behavior of GPLM is converting waste material such as fly ash and slag useful material for making friendly-economic concrete.

In this work, FA is used as a part of the total binder. The FA-based GPLM with added alkali to form the GPLM mortar. The manufacture of GPLM mortar is carried out using the usual practice in concrete technology. High FA content in GPLM produced in ambient temperature achieved high strength [6].

As the demand for GPLM directly increases with the addition FA, the curing temperature takes place an important role in the development of strength. Curing temperature of 70 , 90 and $110{ }^{\circ} \mathrm{C}$ with curing period of one day were used in all mixes.
The aim of the research is to evaluate the effect of fly ash on the properties of GPLM mortar. The primary objectives of this research are as follows:

- To make a new green binder to replace cement, with a low-cost, better mechanical strength and improving absorption properties.

- Study the effect of different proportions of FA in the binder on mechanical properties of GPLM concrete.

- Evaluation of the performance of FA-based GPLM mortar with respect to the strength properties.

\section{Experimental Work}

This Section describes the experimental work. First of all, materials, mixing ratios, production and curing of test samples are explained. This is then followed by the sample types, test parameters and test procedures used. The aim of this research is to evaluate the effect of different amounts of FA on the mechanical and durability of the GPLM mortar.

\subsection{Materials}

The materials utilized for producing GPLM mortar are fly ash as a source material, the combination of sodium silicate and sodium hydroxide as alkaline liquid activator, and superplasticizer in liquid for improving the strength of concrete.

\section{- Fly Ash}

In the present study low calcium fly ash (ASTM Class F) from local sources was utilized as a source material. Table 1 shows physical and chemical compositions of fly ash. Class F fly ash normally produced from burning anthracite or bituminous coal.

Table 1 Physical and chemical properties of fly ash

\begin{tabular}{|l|l|}
\hline Physical and chemical analysis (\%) & FA \\
\hline $\mathrm{CaO}$ & 2.20 \\
\hline $\mathrm{SiO}_{2}$ & 57.20 \\
\hline $\mathrm{Al}_{2} \mathrm{O}_{3}$ & 24.40 \\
\hline $\mathrm{Fe}_{2} \mathrm{O}_{3}$ & 7.10 \\
\hline $\mathrm{MgO}$ & 2.40 \\
\hline $\mathrm{SO}$ & 0.30 \\
\hline $\mathrm{K}_{2} \mathrm{O}$ & 3.40 \\
\hline $\mathrm{Na}_{2} \mathrm{O}$ & 0.40 \\
\hline Loss on ignition $(\mathrm{LOI})$ & 1.50 \\
\hline Specific gravity & 2.250 \\
\hline Specific surface area $\left(\mathrm{m}^{2} / \mathrm{kg}\right)$ & 379.0 \\
\hline Aggregate & \\
\hline
\end{tabular}

Aggregates were used as a fine aggregate locally in western part of Turkey's Southeastern Anatolian Region; Gaziantep for producing fly ash and slag based GPLM mortar.

- Alkaline Activator 


\section{European Journal of Science and Technology}

Sodium based activator (a combination of sodium silicate and sodium hydroxide solution) was chosen as the alkaline activator for activating GPLM concrete. Sodium activator was picked because they were cheaper than potassium activators. The $\mathrm{NaOH}$ used in this study was in pellets from with $97-98 \%$ purity and were dissolved in water at 24 hours prior to mixing. Figure1 shows the preparation of alkali solution.

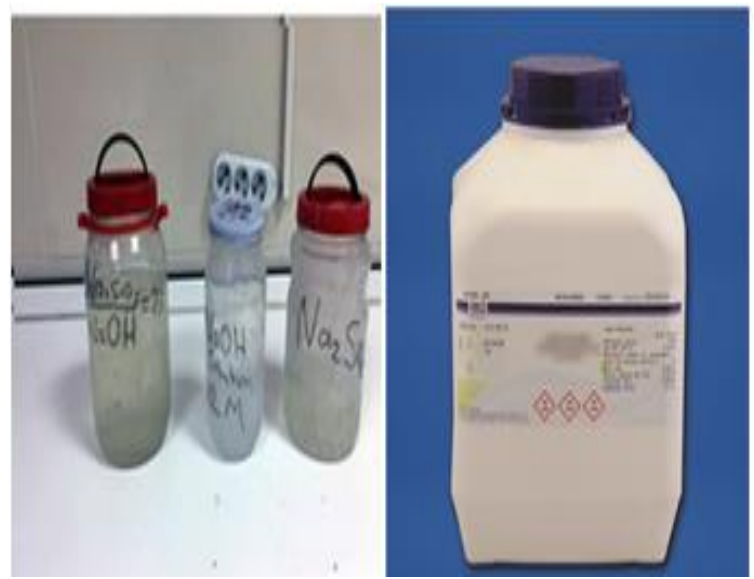

Figure 1 Alkaline activator (Sodium silicate and Sodium hydroxide)

\section{- Superplasticizer}

In order to improve the strength of fresh concrete, highrange water-reducing naphthalene based superplasticizer was added to the mixture, and specific gravity was 1.07. Gelenium 51 was used in this search to develop the strength of concrete. Properties of the superplasticizer is shown in table 2.

Table 2 Properties of superplasticizer

\begin{tabular}{|l|l|}
\hline Properties & Superplasticizer \\
\hline Name & Glenium 51 \\
\hline Color tone & Dark brown \\
\hline State & Liquid \\
\hline Specific gravity $(\mathrm{kg} / 1)$ & 1.07 \\
\hline Chemical description & Polycarboxilate ether \\
\hline
\end{tabular}

\subsection{Manufacture GPLM Mortar}

Alkali activator was prepared by mixing sodium hydroxide and sodium silicate one day in advance to ensure it to cool down in a room at temperature $\left(25^{\circ} \mathrm{C}\right)$. Fly ash and aggregate were first mixed together pan mixer for 3 minutes to ensure homogeneity of the mixture. Then, mortar mixer stopped. The liquid components that contain sodium hydroxide solution, sodium silicate and superplasticizer were added to the dry materials and the mixing continued for further about 5 minutes to produce the fresh fly ash and slag based GPLM mortar. Figure 2 shows the resource material and alkali activator of GPLM concrete.

Then, the fresh GPLM mortar was poured into 50x50x50 mm cube molds directly after mixing in to two layers, as described in the ASTM C109 standard. Moreover, for the compaction of the specimens the rod was employed, and each layer of GPLM mortar was tamped 25 times with a rod. To remove air voids, all the cast specimens were vibrated on a vibrating table for 2 minutes. Figure 2 shows adding alkaline activator to the dry components.

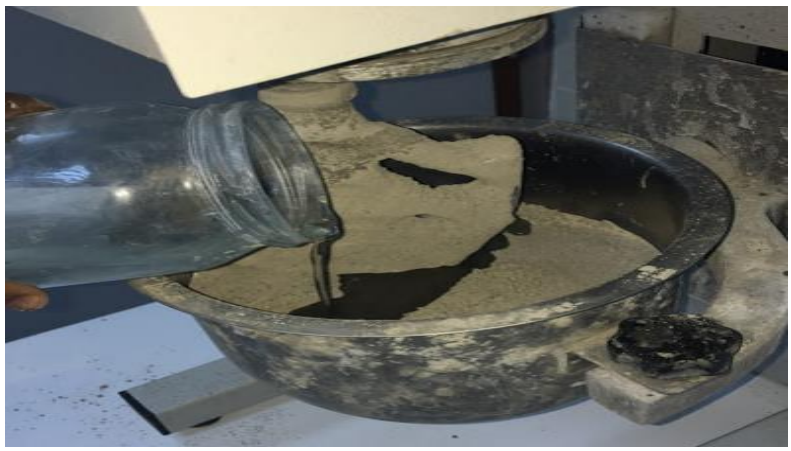

Figure 2 Adding alkaline activator to the dry components

Before pouring the prepared equipment, fresh concrete was poured into molds immediately after mixing, two layers for prismatic samples. As shown in Figure 3, samples were covered with vacuum bagging film to minimize water evaporation during curing temperature.

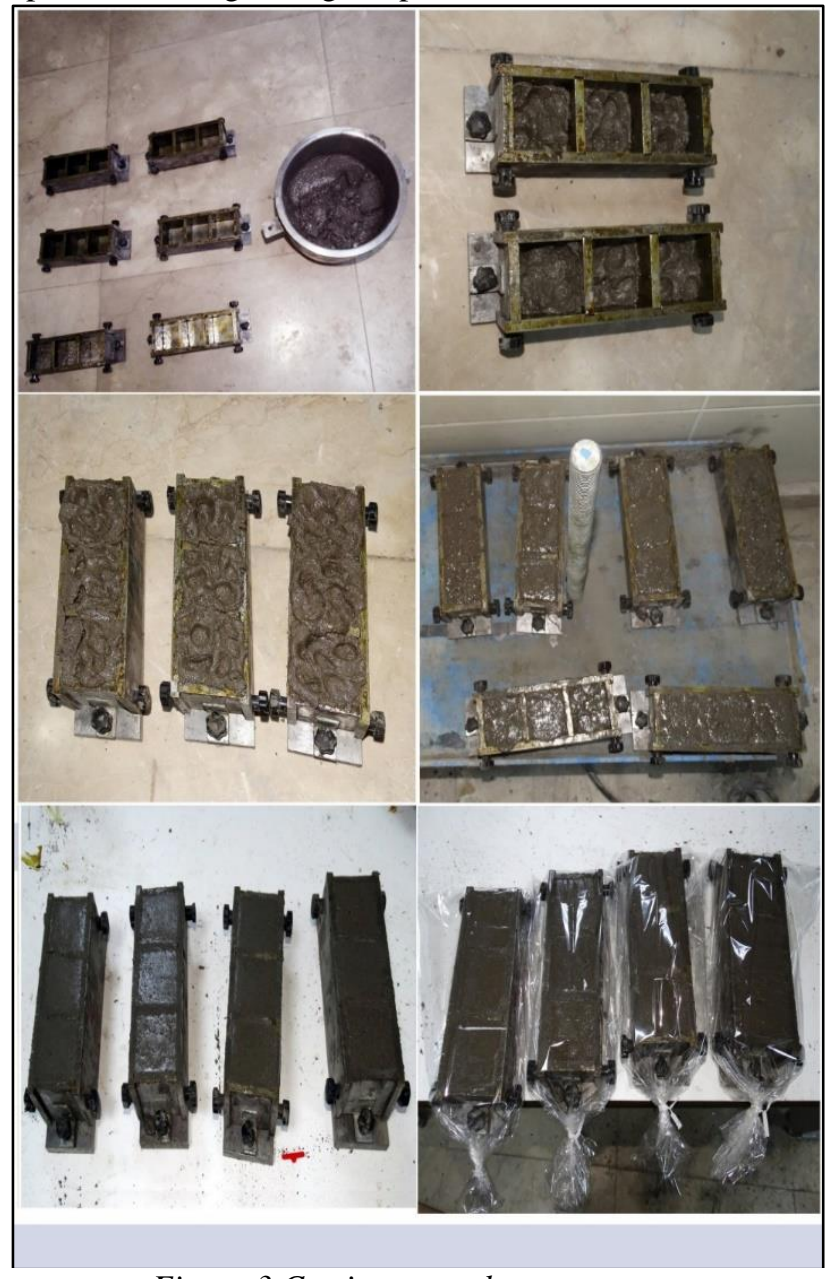

Figure 3 Casting geopolymer mortars

\subsection{Curing}

After casting, for minimizing water evaporation, the test specimens were wrapped with vacuum bagging film at high temperature as shown in Figure 4. In this study dry heat curing was used, the specimens were cured in oven at curing temperature of 70,90 and $110{ }^{\circ} \mathrm{C}$ and curing period is 24 hours. 


\section{Avrupa Bilim ve Teknoloji Dergisi}

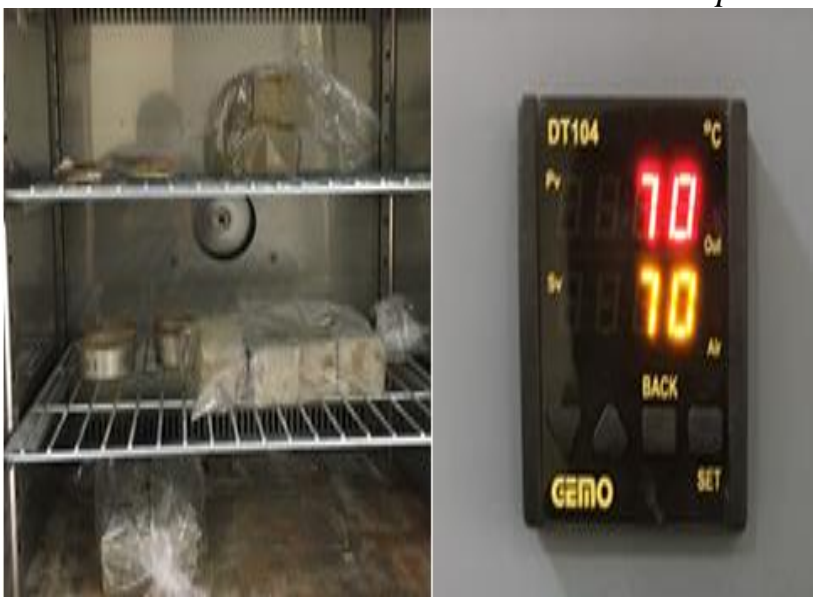

Figure 4 Dry (oven) Curing

\subsection{Mixture Proportion}

Table 3 summarized the detail of mixture proportions based on percentage of fly ash was tried during the experimental research for producing GPLM mortar. Five mixes were tested in this study; each mixture has different proportion of FA as shown in table 3. Main features are:

1- $\quad$ Fly ash was used.

2- $\quad$ Water just used for dissolution $\mathrm{NaOH}$ pellets.

3- $\quad \mathrm{Na} 2 \mathrm{SiO} 3$ was mixed $\mathrm{NaOH}$ in all mixtures.

4- $\quad$ Superplasticizer was used.

5- $\quad$ Curing period was 24 hours for all specimens.

6- Oven dry curing was used.

Table 3 mixture proportions

\begin{tabular}{|l|l|l|l|l|l|}
\hline Mixture & Mix1 & Mix2 & Mix3 & Mix4 & Mix5 \\
\hline Sand & 2639 & 2539 & 2439 & 2339 & 2239 \\
\hline Fly ash & 600 & 700 & 800 & 900 & 1000 \\
\hline Water & 177 & 177 & 177 & 177 & 177 \\
\hline $\begin{array}{l}\text { Sodium } \\
\text { silicate }\end{array}$ & 428.5 & 428.5 & 428.5 & 428.5 & 428.5 \\
\hline $\begin{array}{l}\text { Sodium } \\
\text { hydroxide }\end{array}$ & 171.5 & 171.5 & 171.5 & 171.5 & 171.5 \\
\hline $\begin{array}{l}\text { Super } \\
\text { plasticizer }\end{array}$ & 72 & 72 & 72 & 72 & 72 \\
\hline
\end{tabular}

\section{Experimental tests for GPLM Mortar}

\subsection{Compressive Strength}

In the strength study of materials, compressive strength is the capacity of a material or structure to withstand loads that tend to reduce. Cubes were followed for cement mortar according to ASTM C109. Each mixture was poured into several cubes of mold by filling the mold halfway and vibrating for 30 seconds, filling the mold the rest of the way and vibrating it again for 30 seconds, and then flattening the top. The molds were then covered with plastic and sealed again in vacuum packaging to maintain a moist environment during curing. After mixing the molds, they were placed in the oven at 70,90 and $110^{\circ} \mathrm{C}$ for 24 hours. A $3000 \mathrm{kN}$ capacity digital pressure test machine with a loading speed of $0.5 \mathrm{kN}$ / $\mathrm{sec}$ was used. For each parameter tested, three identical samples were tested according to ASTM C-109 and average compressive strength values are reported in the respective tables and graphs.

The compressive strength of the specimens was calculated using the equation:

f_c $=$ P/A

Where,

$$
\begin{aligned}
& \mathrm{fc}=\text { Compressive strength }(\mathrm{MPa}) \\
& \mathrm{P}=\text { maximum force applied }(\mathrm{kN}), \\
& \mathrm{A}=\text { Cross sectional area }(\mathrm{mm} 2)
\end{aligned}
$$

\subsection{Splitting Tensile Strength}

The hardening of the fly ash-based GPLM mortar samples after 24 hours of curing was performed with a loading speed of $0.1 \mathrm{kN} / \mathrm{sec}$ and split tensile strength in a digital machine with $3000 \mathrm{kN}$ capacity according to ASTM C37. Three

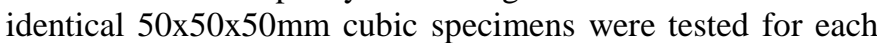
mixture, the result value given and reported in various figures and graphics.

Splitting tensile strength of the specimen was calculated using the expression below

$$
f_{s}=\frac{2 P}{\pi a^{2}}
$$

Where f_s is splitting tensile strength (MPa), P is splitting $\operatorname{load}(\mathrm{N})$, a is dimension of cubic specimen $(\mathrm{mm})$.

\subsection{Water sorptivity test}

Sorptivity can be considered one of the easiest tests to evaluate the permeability of mortar concrete. Water can enter the concrete or mortar samples through capillary suction. It can also measure the rate of absorption liquid entering the mortar concrete by capillary suction. Sorptivity will be determined by measuring capillary water absorption by absorption based on both capillary pressure and effective porosity. According to the Young-Laplace equation, capillary pressure and effective porosity depending on the size of the pores are related to the pore space in gel pores and capillaries according to Neville [7]. The sorptivity test evaluates the amount of capillary rise absorbed by mortar or concrete samples. Three identical specimens were tested, then the side specimen covered with silicone gasket to ensure that water only entered from the bottom of the specimen, followed by the mortar specimens immersed in water. During the test it should be observed that the water level is not kept more than $5 \mathrm{~mm}$ from the lower face of the sample. The time was recorded immediately after the samples were placed in the support device (initial contact with water). The increase in mass gain is weighted at different time intervals of the prism at 1, 4, 9, $16,25,36,49$ and 64 . get to the surface before taking any weight. And we place them on a dry-surface electric pan scale so that the absorbent surface is not touched, and return them to their sponges within 15 seconds.

\section{Experimental Results and Discussion}

\subsection{Compressive Strength}

Compressive strength is considered as one of the most important properties of hardened concrete. It is generally the main property value used to investigate the quality of concrete 
according to ASTM C109. That is why it is important to evaluate whether changes in the mixture composition will affect the early and late compressive strength of GPLM. Compressive strength results of GPLM for cubic molds $50 \times 50 \times 50$ at ages of 1day and with different curing temperature is given in Table 4.

Table 4 Compressive strength of GPLM mortar at different curing temperature $(\mathrm{MPa})$

\begin{tabular}{|c|c|c|c|}
\hline Mixtures & $70^{\circ} \mathrm{C}$ & $90^{\circ} \mathrm{C}$ & $110^{\circ} \mathrm{C}$ \\
\hline Mixture1 & 26.1 & 26.5 & 27.1 \\
\hline Mixture2 & 27.8 & 28.0 & 28.9 \\
\hline Mixture3 & 29.1 & 30.2 & 31.5 \\
\hline Mixture4 & 32.4 & 33.9 & 34.8 \\
\hline Mixture5 & 35.4 & 36.8 & 39.0 \\
\hline
\end{tabular}

It can be seen from that strength development of the GPLM concrete increase when the percentage of FA increase. Comparing the strength developments of the GPLM concrete mixtures of all mixture, it can be seen that the inclusion of FA in the binder has increased compressive strength. The improvement of strength of fly ash-based GPLM mortar is due to the increase of calcium bearing compound in the dissoluted binder which produced reaction product from FA. Moreover, the strength increases with the increase of curing temperature of GPLM.

\subsection{Splitting Tensile Strength}

GPLM mortar is very weak in tension due to its hard brittle nature and is not expected to resist direct stress. Concrete cracks heal when subjected to tensile forces. Therefore, it is necessary to find the split tensile strength of the mortar to determine the load at which the specimen can crack. The results of the split tensile strength summarized in Table 5 can be concluded that the increase in FA content increases the tensile strength of GPLM. The strength increases as the curing temperature of the GPLM increases.

Table 5 Splitting tensile of GPLM mortar at different curing temperature $(\mathrm{MPa})$

\begin{tabular}{|c|c|c|c|}
\hline Mixtures & $70^{\circ} \mathrm{C}$ & $90^{\circ} \mathrm{C}$ & $110^{\circ} \mathrm{C}$ \\
\hline Mixture1 & 2.5 & 2.6 & 2.6 \\
\hline Mixture2 & 3.2 & 3.5 & 3.6 \\
\hline Mixture3 & 3.3 & 3.7 & 3.7 \\
\hline Mixture4 & 3.5 & 3.7 & 3.8 \\
\hline Mixture5 & 3.7 & 3.7 & 3.9 \\
\hline
\end{tabular}

\subsection{Water sorptivity test}

Sorptivity test is one of the most important tests that evaluate the capillary structure of GPLM. The experimental results on water sorptivity at age of 1 day. Test results indicate that the increment in the FA content reduce the sorptivity of GPLM.

\section{Conclusion}

This Chapter presents a brief summary of the study and a set of conclusions drawn from the study. The mechanical properties included in the study are compression and tensile testes while a durability property measured using sorptivity test.

In the present study, the experimental test of different proportions of FA in the binder on mechanical and durability properties of GPLM mortar. Five mixes have been tests; each mixture has different proportion of FA. It can be concluded that GPLM mortar with high percentage of FA gain high compressive and tensile strength.

Test results indicate that the increment in the FA content increases the compressive and tensile strength of GPLM. The strength increases with the increase of curing temperature of GPLM. Moreover, blended GPLM with high percentage of fly ash has less sorptivity.

\section{References}

[1] Mccaffrey, R. (2002). Climate change and the cement industry, Global cement and lime magazine (environmental special issue), 15-19.

[2] Davidovits, J. (1994). Properties of Geopolymer Cements. In Kiev (Ed.), First International Conference on Alkaline Cements and Concretes, 1, 131-149.

[3] Davidovits, J. (1988a). Geopolymer Chemistry and Properties, Paper presented at the Geopolymer '88, First European Conference on Soft Mineralurgy, Compiegne, Franc.

[4] Davidovits, J. (1988b). Geopolymers of the First Generation: SILIFACE-Process Paper presented at the Geopolymer '88, First European Conference on Soft Mineralurgy, Compiegne, France.

[5] Temuujin, J., van Riessen, A., \& MacKenzie, K. J. D. (2010). Preparation and characterisation of fly ash based geopolymer mortars. Construction and Building Materials, 24 (10), 1906-1910.

[6] Van Jaarsveld, J. G. S., Van Deventer, J. S. J., \& Lukey, G. C. (2003). The characterisation of source materials in fly ash-based geopolymers. Materials Letters, 57 (7), 1272-1280.

[7] Neville, A.M. (2000). Properties of Concrete. Longman scientific and Technical 